\title{
Supplemental Ascorbic Acid and Prevention of Neonatal Calf Diarrhoea
}

\author{
S. SAHINDURAN, M. K. ALBAY \\ University of Akdeniz, Faculty of Veterinary Medicine, Department of Internal \\ Medicine, Burdur, Turkey
}

Received May 13, 2003

Accepted June 17, 2004

\begin{abstract}
Sahinduran S., M. K. Albay: Supplemental Ascorbic Acid and Prevention of Neonatal Calf Diarrhoea. Acta vet. Brno 2004, 73: 221-224.

The experiment evaluated the influence of ascorbic acid on the prevention of neonatal calf diarrhoea. Thirty-five Holstein newborn calves were used in the experiment. Ascorbic acid was administered orally to the trial group calves $(n=25)$ as follows: three times $1000 \mathrm{mg}$ a day during the first week; three times $500 \mathrm{mg}$ a day during the second week; and three times 250 $\mathrm{mg}$ a day during the third week. No ascorbic acid was administered to control group $(\mathrm{n}=10)$. Calves of both groups were allowed to take sufficient colostrum during the first hours of life and they were fed 4.5 liters of milk/d during the first three weeks. Jugular blood was collected in EDTA containing vial at 7, 14, 21 days of age. Diarrhoea was observed in two calves (8\%) among the trial group and four calves (40\%) among the control group and calves with diarrhoea were excluded from analysis. Mean plasma ascorbic acid values in control group during the first, second and third weeks $\left(45.61 \pm 2.80 \mu \mathrm{mol} \cdot \mathrm{l}^{-1}, 40.81 \pm 3.47 \mu \mathrm{mol} \cdot \mathrm{l}^{-1}, 40.81 \pm 3.47 \mu \mathrm{mol} \cdot \mathrm{l}^{-1}\right.$, respectively) were significantly lower than values in trial group $\left(88.63 \pm 6.07 \mu \mathrm{mol} \cdot \mathrm{1}^{-1}, 79.67\right.$ $\pm 5.70 \mu \mathrm{mol} \cdot \mathrm{l}^{-1}, 79.67 \pm 5.70 \mu \mathrm{mol} \cdot \mathrm{l}^{-1}$, respectively; $\left.p<0.001\right)$. Moreover, plasma ascorbic acid values for calves without diarrhoea were significantly higher than plasma ascorbic acid values for calves suffering from diarrhoea $(p<0.05)$. Supplementation of neonatal calves with ascorbic acid has a potential for the prevention of neonatal enteritis.
\end{abstract}

Holstein calves, oral ascorbic acid, E. coli diarrhoea, Staphylococcus diarrhoea, colostrum

Ascorbic acid is synthesized by all species and is not an important dietary essential in any of the domestic animals. Synthesis occurs in tissues and although its blood level falls after birth in the newborn calf it begins to rise again at about 3 weeks of age (Blood and Radostits 1989). Ascorbic acid is an essential nutrient for the immune system. Cattle can produce ascorbic acid in the liver except during the first few weeks of life (Hemingway 1991). Cow's milk is a poor source of ascorbic acid and its amount in milk (1-2 mg/100 ml) is not adequate to fulfill the requirements of 1-week-old calves, and if no supplement is added to colostrum or milk, the ascorbic acid level in plasma decreases considerably in few days (Kolb 1992); calves therefore require exogenous ascorbic acid (Heming w ay 1991). Ascorbic acid deficiency can often result in impaired resistance to infectious organisms (Cummins and Brunner 1989; Hemingway 1991; Seifi et al. 1996). Increased demands for ascorbic acid occur in acute or chronic disease conditions because of increased tissue utilization (Hemingway 1991). Calves with enteric infection had lower concentrations of ascorbic acid in plasma than did healthy calves (Hemingway 1991; Hidiroglu et al. 1995). It has been suggested that there is a need for ascorbic acid supplements in modern dairy-calf-rearing operations (Hemingway 1991; Seifi et al. 1996).

The purpose of this trial was to establish the effectiveness of ascorbic acid as a prevention of neonatal calf diarrhoea.

\footnotetext{
Address for correspondence:

Sima Sahinduran, DVM, PhD

Akdeniz University, Faculty of Veterinary Medicine

Department of Internal Medicine.

15100-Burdur Turkey
}

\author{
Phone: + 90-248-2344500 \\ Fax: + 90-248-2344505 \\ E-mail: simasahin@akdeniz.edu.tr \\ http://www.vfu.cz/acta-vet/actavet.htm
}




\section{Materials and Methods}

The materials of this study were obtained from the farms, in the province of Burdur. A total of 35 newborn Holstein calves, 25 as trial group and 10 as control group, were used. Trial and control group calves were chosen among the calves of the same farm in order to obtain a suitable sampling.

Trial group calves were given ascorbic acid orally; three times $1 \mathrm{~g}$ (a total of $3 \mathrm{~g}$ ) a day in the first week; three times $500 \mathrm{mg}$ (a total of $1.5 \mathrm{~g}$ ) a day in the second week; and three times $250 \mathrm{mg}$ (a total of $750 \mathrm{mg}$ ) a day in the third week. No ascorbic acid was administered to control group during three weeks. No animals were vaccinated. All calves received colostrum during the first hours of life and continued to be fed with 1.5 liters of milk from their mother three times a day $(6$ a.m., 3 p.m. and 9 p.m. $)$ during the first three weeks. Excellent quality alfalfa was given free choice after the first week for the development of rumen microflora. Both groups of calves were separated from their mothers after birth and were housed in individual metal pens. All calves were given thorough clinical examination daily, and the findings (general condition, fecal consistency, body temperature) were recorded continuously. Cows were fed on dry hay, corn silage and dry period concentrates feed (mainly barley, cottonseed meal and sunflower meal). Dicalcium phosphate was added to concentrates. Wide spectrum antibiotics, (penicillin, amoxicillin + clavulanic acid) were used for calves with diarrhoea. All calves with diarrhoea received adequate oral and/ or parenteral fluid and electrolyte therapy.

Jugular blood was collected in EDTA containing vials at 7, 14, 21 days of age in both groups. Plasma of these samples was gained in the laboratory using Hettich Zentrifugen Universal 30F model centrifuge device by centrifuging 3000 cycles during 7 minutes. Plasma ascorbic acid levels were measured by using Shimadzu UV1601 model spectrophotometer device according to the methods of Kyaw (Kyaw 1978). Statistical Analysis of the results obtained in this study was made according to SSPS for MS. WINDOWS Release 10.0 Program (Dependent-t and Mann-Whitney tests).

\section{Results}

Two calves in the trial group and four calves in the control group developed diarrhoea. Staphylococcus spp. $(\mathrm{n}=2)$ and Escherichia coli $(\mathrm{n}=4)$ were isolated from rectal samples. After antibiogram results, diarrhoeic calves with St. spp. were treated with amoxicillin and clavulanic acid combination, whereas diarrhoeic calves with E. coli were treated with penicillin. They responded well to the treatment and no calves died of diarrhoea.

In Table 1, mean plasma ascorbic acid values between trial and control groups are indicated for three weeks.

Table 1

Mean plasma ascorbic acid values between trial and control groups first three weeks $\left(\mu \mathrm{mol} \cdot \mathrm{l}^{-1}\right)$

\begin{tabular}{|c|c|c|c|c|c|c|c|c|c|c|}
\hline Weeks & $\mathrm{n}$ & Trial & $\mathrm{n}$ & Control & $p<$ & $\mathrm{n}$ & Trial $^{*}$ & $\mathrm{n}$ & Contro $^{*}$ & $p<$ \\
\hline $1^{\text {st }}$ & 25 & $83.84 \pm 6.65$ & 10 & $40.51 \pm 3.37$ & 0.001 & 23 & $88.63 \pm 6.07$ & 7 & $45.61 \pm 2.80$ & 0.001 \\
\hline $2^{\text {nd }}$ & 25 & $75.77 \pm 5.92$ & 10 & $36.82 \pm 2.78$ & 0.001 & 23 & $79.67 \pm 5.70$ & 6 & $40.81 \pm 3.47$ & 0.001 \\
\hline $3^{\text {rd }}$ & 25 & $64.47 \pm 5.27$ & 10 & $31.25 \pm 2.66$ & 0.001 & 23 & $79.67 \pm 5.70$ & 6 & $40.81 \pm 3.47$ & 0.001 \\
\hline
\end{tabular}

* = calves with no diarhoea

According to the variance analyses, ascorbic acid values between trial and control groups were considered significant $(p<0.001)$.

Table 2

Mean plasma ascorbic acid values between trial and control groups during the first three weeks $\left(\mu \mathrm{mol} \cdot \mathrm{l}^{-1}\right)$

\begin{tabular}{|c|c|c|c|c|c|c|c|c|c|c|}
\hline Weeks & & \multicolumn{4}{|c|}{ Trial } & \multicolumn{5}{c|}{ Control* } \\
\hline & $\mathrm{n}$ & Non-Diarrhoea & $\mathrm{n}$ & Diarrhoea & $p<$ & $\mathrm{n}$ & Non-Diarrhoea & $\mathrm{n}$ & Diarrhoea & $p<$ \\
\hline 1st & 23 & $88.63 \pm 6.07$ & 2 & $28.41 \pm 2.43$ & 0.05 & 7 & $45.61 \pm 2.80$ & 3 & $28.41 \pm 3.41$ & 0.05 \\
\hline 2nd & 25 & $75.77 \pm 5.92$ & 0 & 0 & - & 9 & $37.37 \pm 3.04$ & 1 & $31.82 \pm 0$ & ns $^{*}$ \\
\hline 3rd & 25 & $64.47 \pm 5.27$ & 0 & 0 & - & 10 & $31.25 \pm 2.66$ & 0 & 0 & \\
\hline
\end{tabular}

$*$ ns $=$ not significant

First week plasma ascorbic acid values between diarrhoeic and non-diarrhoeic calves in trial and control groups were considered significant $(p<0.05)$. 
Diarrhoea was observed in two calves out of $25(8 \%)$ in the trial group during the first week. On the other hand, no diarrhoea was observed during the second and third weeks for trial group. In the control group, four calves out of 10 (three calves in the first week and one calve in the second week) were diagnosed with diarrhoea (40\%). No diarrhea was observed in the third week for control group (Table 2).

\section{Discussion}

When the plasma ascorbic acid levels of the trial group calves are compared to control group calves during the first, second and third weeks, values of trial group are significantly higher than the control group $(p<0.001)$. Our findings, shown in Table 2, comply with the results of previous studies (Hidiroglu et al. 1995; Serpek et al. 1989).

Weekly mean plasma ascorbic acid levels of the control and trial group calves are indicated in Table 2. Plasma ascorbic acid levels of both groups tended to decrease throughout three weeks. These results are similar to the findings of prior experiments. It has been previously reported that calves were observed to have high plasma vitamin $\mathrm{C}$ concentrations at birth. However, an obvious decline in plasma vitamin $\mathrm{C}$ concentrations was detected after the first days of life (Itzel 1984; Pallud an and Wegger 1984).

In the current experiment, when the amount of given ascorbic acid decreased, plasma ascorbic acid level also decreased numerically. According to Itzel (1984), daily oral administration of $2.5 \mathrm{~g}$ vitamin $\mathrm{C}$ to newborn calves increased their plasma ascorbic acid level until $7^{\text {th }}$ day of their lives, but had no effect after the $14^{\text {th }}$ day. In our study, although there was a decrease in the weekly plasma ascorbic acid level of both groups, the ascorbic acid level of the trial group was examined greater than the control group in each of the three weeks $(p<0.001)$. However, according to Pallud an and Wegger (1984) and Hidiroglu et al. (1995), the ascorbic acid level in the plasma was dependent on the amount of vitamin $\mathrm{C}$ supplementation that would be taken externally. Our findings agree with the conclusions of above mentioned researchers.

As mentioned previously, although just two of 25 animals in the trial group were observed with diarrhoea in the first week, no diarrhoea was observed in the second and third weeks. However, three of 10 animals in the control group were observed with diarrhoea, and no diarrhoea case was observed in the third week.

According to the results, plasma ascorbic acid values of the non-diarrhoeic calves were found significantly higher than those of the diarrhoeic calves $(p<0.05)$. These results agreed with the conclusions of the other researchers (Hemingway 1991; Jagoš et al. 1981; Jagoš et al. 1977) who claimed that plasma ascorbic acid levels of calves with enteric and respiratory infections were lower than plasma ascorbic acid levels of healthy calves.

In this study, the calves with diarrhoea formation had significantly lower plasma vitamin $\mathrm{C}$ concentration than calves with no diarrhoea $(p<0.05)$. It was determined that the risk of diarrhoea formation was significantly minimized in the animals with high ascorbic acid level.

As a result, it can be concluded that administration of ascorbic acid to newborn calves was especially important for the prevention of neonatal enteritis, and that giving oral ascorbic acid to calves can be useful.

\section{Účinek př́idavku kyseliny askorbové v prevenci neonatálního průjmu telat}

V pokusu byl hodnocen vliv kyseliny askorbové na prevenci neonatálního průjmu telat. Pro pokus bylo použito 35 novorozených telat holštýnského plemene. Kyselina askorbová byla podána orálně třem skupinám telat $(n=25)$ podle následujícího schématu: první týden třikrát denně $1000 \mathrm{mg}$, druhý týden tř̌ikrát denně $500 \mathrm{mg}$ a třetí týden třikrát denně $250 \mathrm{mg}$. Kontrolní skupině $(\mathrm{n}=10)$ podána nebyla.Telata obou skupin sála během prvních hodin 
života kolostrum a poté byla napájena 4,5 1 mléka denně po první tři týdny. Krev z v. jugularis byla odebírána 7., 14. a 21. den života do zkumavky s EDTA. Průjem byl zaznamenán u dvou telat (8\%) z prvních tří skupin a u čtyř telat (40\%) z kontrolní skupiny. Telata s průjmem byla vyřazena $\mathrm{z}$ analýzy. Průměrná plazmatická koncentrace kyseliny askorbové v kontrolní skupině během prvního, druhého a tř̌etího týdne $\left(45,61 \pm 2,80 \mu \mathrm{mol} \cdot \mathrm{l}^{-1}\right.$; $\left.40,81 \pm 3,47 \mu \mathrm{mol} \cdot \mathrm{l}^{-1} ; 40,81 \pm 3,47 \mu \mathrm{mol} \cdot \mathrm{l}^{-1}\right)$ byla podstatně nižší než u telat prvních tř́i skupin $\left(88,63 \pm 6,07 \mu \mathrm{mol} \cdot \mathrm{l}^{-1} ; 79,67 \pm 5,70 \mu \mathrm{mol} \cdot \mathrm{l}^{-1} ; 79,67 \pm 5,70 \mu \mathrm{mol} \cdot \mathrm{l}^{-1} ; p<0,001\right)$. Plasmatická koncentrace kyseliny askorbové u telat bez průjmu byla podstatně vyšší než u telat s průjmem $(p<0,05)$. Př́ídavek kyseliny askorbové novorozeným telatům působí preventivně proti neonatální enteritidě.

\section{Acknowledgements}

This study was supported by University of Akdeniz, Fund of Research Projects, Grant No: 2001.01.0108.02.

\section{References}

BLOOD, DC, RADOSTITS, OM 1989: Veterinary Medicine. $7^{\text {th }}$ Ed. Baillière Tindall, London, 1224 p.

CUMMINS, KA, BRUNNER, CJ 1989: Dietary ascorbic acid and immune response in dairy calves. J Dairy Sci 72: $129-134$

HEMINGWAY, DC 1991: Vitamin C in the prevention of neonatal calf diarrhea. Can Vet J 32:184

HIDIROGLU, M, BATRA, TR, IVAN, M 1995: Effect of supplemental vitamins E and C on the immune responses of calves. J Dairy Sci 78: 1578-1583

ITZEL, L 1984: Ascorbic acid metabolism in ruminants. In: Workshop. Ascorbic acid in domestic animals. Ed. I Wegger, FJ Tagwerker, J Moustgaard. Royal Danish Arg Soc 120-130

JAGOŠ, P, BOUDA, J, DVOŘ́́K, R 1977: Ascorbic acid levels in the bronchopneumonia of calves. Vet Med (Praha) 22: 133-136

JAGOŠ, P, BOUDA, J, DVOŘÁK, R, ONDROVÁ, J 1981: Comparison of biochemical parameters in the blood of healthy and disease calves in a large barn. Vet Med (Praha) 26: 573-80

KOLB, E 1992: Recent findings of the significance of ascorbic acid for domestic animals and its uses in veterinary medicine. Tierarzt Umsch 47: 163-175

KYAW, A 1978: A simple colorimetric method for ascorbic acid determination in blood plasma. Clin Chim Acta 86: $153-157$

PALLUDAN, B, WEGGER, I 1984: Plasma ascorbic acid in calves. Relation to age and individuality. In: Workshop. Ascorbic acid in domestic animals. Ed. I Wegger, F J Tagwerker, J Moustgaard. Royal Danish Agr Soc. pp. 120-130

SEIFI, HA, MOKHBER DEZFULY, MR, BOLURCHI, M 1996: The effectiveness of ascorbic acid in the prevention of calf neonatal diarrhoea. J Vet Med B 43: 189-191

SERPEK, B, ASLAN, V, TUNCER, SD, ATES, M 1989: Ishalli buzagilarda serum vitamin C ve seruloplazmin düzeyleri ile vitaminin tedaviye etkisi. L H A E D 29: 37-52 